\title{
Agriculture Situation in Punjab: An Analysis of Transformations from Labour Intensive Farming to Capital Intensive Farming
}

\author{
Naresh Kumar \\ Department of Economics, Punjabi University, Patiala, Punjab, India \\ Corresponding author: nareshrana.eco@gmail.com
}

\begin{abstract}
There is no doubt that Punjab farming is capital intensive and agricultural production increased with the use of machinery, high yielding varieties of seeds, pesticides and fertilizers. But the use of technology made agriculture more capital intensive. Punjab farmers are suffering from stagnated agricultural production and their expenditure on agricultural inputs are increasing over the time. This situation creates financial problems for the farming class. The present paper tried to shows the current situation of Punjab's agriculture in terms of operational land holding, productivity, irrigational sources, marketing of agricultural produced, and transformation from labour intensive to capital intensive farming etc.

Highlights

( Punjab farmers are suffering from stagnated agricultural production and their expenditure on agricultural inputs are increasing over the time.

(- This situation creates financial problems for the farming class. To overcome the losses and meet the expenditure farmers needs to take loans.

(0 To return the loans many times farmers sell their land and moving outside the agriculture to support their livelihood.
\end{abstract}

Keywords: Agriculture Sector, Punjab Economy, Production, Crops, Large Small, Marginal Framers

Indian economy has witnessed significant change since independence in every sector especially in agriculture. Agricultural production and productivity has increased with the implementation of new agricultural technologies. Better quality of seeds, fertilizers, pesticides, irrigation facilities commonly known as green revolution have had the significant impact on agriculture. Production technology related to agriculture has always been under change, but this change is slower than the change in industrial technology. Indian agriculture has changed from a subsistence economy to a market oriented one. Green revolution with the use of high yield varieties of seeds, intensive use of fertilizers, better irrigation facilities and more machinery use has played a whittle role in this transformation. This change has not been uniform all over the country. Impact of green revolution can be seen in the development of agriculture in Punjab state as Punjab has better irrigation structure. Another point which comes up is the impact of green revolution on different size of holdings. Use of technology, production and ultimately income from agriculture depends on the size of operational holding. New high-yielding varieties of seeds, chemical fertilizers, pesticides and insecticides are commonly used. Adoption of new technologies has increased agricultural production of the state and has also raised the growth rate of the state. With the use of new technology, agriculture has become commercial in nature, which was once considered as subsistence.

There is no doubt that Punjab farming is capital intensive and agricultural production increased 


\section{P) Kumar}

with the use of machinery, high yielding varieties of seeds, pesticides and fertilizers. But the use of technology made agriculture more capital intensive (Singh 2008), which was more in favour of large farmers because only they could easily afford modern agricultural machinery, chemical fertilizers, insecticides/pesticides etc.. This non-affordances in case of marginal and small farmers increased inequality as well as indebtedness in rural areas (Junankar, 1975). Inequality increased not only in farm income and land holdings but in other kinds of assets too. Modern agricultural machinery, chemical fertilizers, insecticides/pesticides etc. have benefited the large farmers more. Small and marginal farmers continue to conduct their agricultural activities with the traditional methods. New technology being capital intensive, so marginal and small farmers are unable to spend money on irrigation, machinery, fertilizers and better quality seeds. This disability of small and marginal farmers has pressed them into more poverty and indebtedness, along with increasing inequality among different strata of farmers.

At present farm productivity is stagnate thus rate of return from agriculture is decreasing. A large number of studies related to Punjab agriculture are the view that stagnation in agricultural productivity is result of optimum use of technology, over exploitation of soil and water. Other reasons behinds this slow down in agriculture are less institutional credit facilities, lack of modern market, rural infrastructure, unsuitable input pricing policies etc. With the stagnation in farm productivity farm income and profitability has also decreasing.

The main consequences of agrarian distress in Punjab are that farmers are leaving the agriculture, because they cannot bear the pressure and stand with the present situation. But without any skills it is difficult for them to find a suitable work in industrial sector. Thus a large number of people are there who do not have any job in rural areas. This is the main reason behind this research to access the situation with fresh look.

\section{Objectives, Data Sources and Methodology}

This study mainly focus on what are the different causes of agrarian distress in Punjab. For this secondary data has been used collected from agricultural census and Statistical abstract of Punjab 2015. This paper has been divided in three sections. First section is introduction to the concept. In second section objectives and data methodology has been given. Third section explains number of operational holdings by size groups, net area sown, area under different crops and production of different crops.

Number of total operational holdings has declined during 1970-71 to 2010-11 with some ups and downs in between. Share of different size groups has also changed during the same period. Total number of operational holdings was 137592 in 1970-71. In these holdings 37.63 per cent holdings were of marginal size and 38.45 per cent holdings belong to medium size category. Share of marginal size class

Table 1: Size of operational holding land by size of groups in Punjab

\begin{tabular}{cccccc}
\hline $\begin{array}{c}\text { Year/size } \\
\text { group }\end{array}$ & $\begin{array}{c}\text { Marginal } \\
\text { (below 1 hect) }\end{array}$ & $\begin{array}{c}\text { Small } \\
\mathbf{( 1 - 2} \text { hect) }\end{array}$ & $\begin{array}{c}\text { Medium } \\
\mathbf{( 2 - 1 0 ~ h e c t )}\end{array}$ & $\begin{array}{c}\text { Large } \\
\text { (10 and above) }\end{array}$ & Total \\
\hline $1970-71$ & $517568(37.63)$ & $260083(18.91)$ & $528858(38.45)$ & $68883(5.01)$ & $1375392(100)$ \\
$1980-81$ & $198060(19.42)$ & $199368(19.55)$ & $548624(53.79)$ & $73940(7.25)$ & $1019992(100)$ \\
$1990-91$ & $295668(26.47)$ & $203842(18.25)$ & $550269(49.27)$ & $67172(6.01)$ & $1116951(100)$ \\
$2000-01$ & $122760(11.23)$ & $173071(15.83)$ & $629185(57.56)$ & $72356(6.62)$ & $1093073(100)$ \\
$2010-11(\mathrm{P})$ & $164431(15.62)$ & $195439(18.57)$ & $622966(59.19)$ & $69718(6.62)$ & $1052554(100)$ \\
\hline
\end{tabular}

Source: Statistical abstract of Punjab 2015; Note: The figures shown in parentheses denote the percentages.

Table 2: Net area sown (thousand hectares) and \% to total area in Punjab

\begin{tabular}{cccccccc}
\hline & $\mathbf{1 9 6 0 - 6 1}$ & $\mathbf{1 9 7 0 - 7 1}$ & $\mathbf{1 9 8 0 - 8 1}$ & $\mathbf{1 9 9 0 - 9 1}$ & $\mathbf{2 0 0 0 - 0 1}$ & $\mathbf{2 0 1 0 - 1 1}$ & $\mathbf{2 0 1 3 - 1 4}$ \\
\hline NAS & $3757(75)$ & $4053(81)$ & $4191(83)$ & $4218(84)$ & $4250(84)$ & $4158(83)$ & $4145(82)$ \\
\hline
\end{tabular}

Source: Statistical abstract of Punjab 2015. 
decreased to 19.42 per cent in 1980-81 from 37.63 per cent in 1970-71. It increased to 26.47 per cent in next decade but again decreased drastically to 11.23 per cent in 2000-01. Finally it reached to 15.62 per cent, with a slight increase, in 2010-11 which is less the half share of this class in 1970-71. Number of marginal farmer also decreased from 517568 in 1970-71 to 164431 in year 2010-11. Share of small sized farmers remained almost same with some variations during 1970-71 to 2010-11 but there actual number decreased from 260083 to 195439 in the same period. Number of medium sized operational holdings was 528858 in 1970-71 which was 38.45 per cent of total operational holdings. In 2010-11 share of medium sized holdings was 59.19 per cent of total operational holdings and actual number was 622966 with a slight negative change from previous given year 2000-01 (See table 1).

In 1960-61 net area sown under all crops was 3757 thousand hectares which increased to 4053 thousand hectares in 1970-71. This was the period of green revolution in Punjab. Due to new agricultural technologies farmers were increasing land under crops, so net area sown increased from 75 per cent of total area to 81 per cent of total area. After this decade there was increase in net sown area but it was lower than the decade of 1960-61 to 1970-71. In 1990-91 net area sown was 4218 thousand hectares which increased to 4250 hectares in 20001-01. But after that there is a decreasing trend in net area sown, in 2010-11 net area sown decreased to 4158 thousand hectares and farther to 4145 thousand in 2013-14 (given in table 2).

As we can see there was a crop diversification in year 1960-61, there was area under different crops like jowar, bajra, maize, barley, pulses and oil seeds other than the rice and wheat. In 1970-71 area under rice, bajra, maize, wheat, oil seeds increased from previous decade. But after that decade area under all other crops tend to fall over the time other than the wheat and rice. Area under these two major crops increased during 1960-61 to 2014-15 (shown in table 3).

Area under only rice and wheat increased positively during 1960-61 to 2013-14 (Table 4). Area under rice increased with an annual compound growth of 4.827 during the given period, area under wheat increased by 1.714 per cent during the same period. Growth rate for cotton crop remain almost zero in this period. All other crops have shown negative growth in the given period. This shows that crop diversification of agriculture is vanishing and agriculture has entered in mono-crop system.

Above table shows data related to water table behavior in Punjab. Depth of water level has been shown at two different time points June (pre-monsoon) and October (post-monsoon). As the area under rice increases, this is major water consuming crop. Area under rice increased from 227 thousand hectares to 2851 with an annual increase of 4.89 per cent during 1960-61 to 2013-14. More and more water has been used by farmer with less re-chargeability of water level. Water level which was at 6.827 meter in June 1973 decreased to 11.552 meter in 2005. Water level decreased in post monsoon period too. Water level was at 5.9 meter in 1973, it decreased to 10.964 meter in 2005.

There was increase in total production of all given crops during 1960-61 to 1970-71 because of the green revolution or new agriculture police adopted by the

Table 3: Area under different crops (thousand hectares)

\begin{tabular}{ccccccccccc}
\hline Year/ Crops & Rice & Jowar & Bajra & Maize & Wheat & Barley & $\begin{array}{c}\text { Total } \\
\text { Pulses }\end{array}$ & $\begin{array}{c}\text { Total Oil } \\
\text { Seeds }\end{array}$ & Cotton & Sugarcane \\
\hline $1960-61$ & 227 & 6 & 123 & 327 & 1400 & 66 & 903 & 185 & 447 & 133 \\
$1970-71$ & 390 & 5 & 207 & 555 & 2299 & 57 & 414 & 295 & 397 & 128 \\
$1980-81$ & 1183 & 1 & 69 & 382 & 2812 & 65 & 341 & 138 & 649 & 71 \\
$1990-90$ & 2015 & - & 12 & 188 & 3273 & 37 & 143 & 104 & 701 & 101 \\
$2000-01$ & 2612 & - & 6 & 165 & 3408 & 32 & 54 & 86 & 474 & 121 \\
$2010-11$ & 2826 & - & 3 & 133 & 3510 & 12 & 20 & 56 & 483 & 70 \\
$2014-15(E)$ & 2894 & - & - & 126 & 3505 & 11 & 13 & 46 & 420 & 94 \\
\hline
\end{tabular}

Source: Statistical abstract of Punjab 2015. 
Table 4: Annual compound growth rate of area under different crops

\begin{tabular}{cccccccccc}
\hline Year/ Crops & \multirow{2}{*}{ Rice } & Bajra & Maize & Wheat & Barley & $\begin{array}{c}\text { Total } \\
\text { Pulses }\end{array}$ & $\begin{array}{c}\text { Total Oil } \\
\text { Seeds }\end{array}$ & Cotton & Sugarcane \\
\hline 1960-61 to 1970-71 & 5.561 & 5.34 & 5.43 & 5.09 & -1.46 & -7.50 & 4.78 & -1.18 & -0.38 \\
1970-71 to 1980-81 & 11.736 & -10.40 & -3.67 & 2.03 & 1.32 & -1.92 & -7.32 & 5.04 & -5.72 \\
1980-81 to 1990-91 & 5.470 & -16.05 & -6.84 & 1.53 & -5.48 & -8.32 & -2.79 & 0.77 & 3.59 \\
1990-91 to 2000-01 & 2.629 & -6.70 & -1.30 & 0.41 & -1.44 & -9.28 & -1.88 & -3.84 & 1.82 \\
2000-01 to 2010-11 & 0.791 & -6.70 & -2.13 & 0.30 & -9.34 & -9.46 & -4.20 & 0.19 & -5.33 \\
2010-11 to 2014-15 & 0.596 & -100.00 & -1.343 & -0.036 & -2.152 & -10.210 & -4.799 & -3.434 & 7.648 \\
1960-61 to 2014-15 & 4.827 & -100.00 & -1.751 & 1.714 & -3.264 & -7.553 & -2.544 & -0.115 & -0.641 \\
\hline
\end{tabular}

Source: Statistical abstract of Punjab 2015.

Table 5: Water table behaviour in Punjab (in meters)

\begin{tabular}{ccccccccc}
\hline Year & June & October & Year & June & October & Year & June & October \\
\hline 1973 & 6.827 & 5.9 & 1984 & 6.832 & 6.109 & 1995 & 8.815 & 7.049 \\
1974 & 6.643 & 6.594 & 1985 & 7.25 & 6.234 & 1996 & 8.118 & 6.933 \\
1975 & 7.234 & 5.87 & 1986 & 7.178 & 6.675 & 1997 & 8.279 & 7.143 \\
1976 & 6.562 & 5.362 & 1987 & 7.356 & 7.742 & 1998 & 8.213 & 6.99 \\
1977 & 6.418 & 5.174 & 1988 & 8.487 & 6.023 & 1999 & 8.336 & 7.839 \\
1978 & 6.301 & 5.307 & 1989 & 7.437 & 7.105 & 2000 & 8.916 & 8.44 \\
1979 & 6.064 & 6.2 & 1990 & 7.871 & 6.233 & 2001 & 9.622 & 8.745 \\
1980 & 6.995 & 6.139 & 1991 & 7.366 & 6.877 & 2002 & 9.834 & 9.616 \\
1981 & 6.706 & 6.588 & 1992 & 7.812 & 7.305 & 2003 & 10.456 & 9.726 \\
1982 & 6.761 & 6.716 & 1993 & 8.507 & 7.606 & 2004 & 11.122 & 10.937 \\
1983 & 6.716 & 5.98 & 1994 & 9.013 & 7.724 & 2005 & 11.552 & 10.964 \\
\hline
\end{tabular}

Source: Singh 2011.

farmers and government itself. Second reason for increase in total production of crops was that area under these crops increased during the given period. But after 1970-71 this increase in total production is visible only in two crops rice and wheat. All other crops showed fluctuations in production. Production of jowar is zero and production of bajra is only 1 thousand. Production of pulses has shown a decreasing trend after 1970-71, same can be said for the oil seeds. Total production of cotton, which is a major crop of Malwa region, increased till 1990-91 but after that it has shown fluctuations in its production figures. Maize, cotton and sugarcane are the other three cops which have shown positive growth in the given period of 1960-61 to 2013-14 (as it can be observed from table 6).

Production of rice, maize, wheat and cotton has shown positive growth rates during 1960-61 to 2014-15. Production of rice increased with an annual compound growth rate of 7.453 in the given period.
Annual compound growth rate of rice was highest during the decade of $1970-71$ to $1980-81$ at 16.735 . Maize has shown fluctuation in growth rates, where as production of wheat increased at 4.079 per cent in the said period. Cotton also shown positive growth rate in the given period except for the decade of 1990-91 to 2000-01 when its growth rate was negative at 4.544 per cent annually (see table 7 ).

With the use of high yielding variety of seeds, irrigation, machinery and chemical fertilizers yield per hectare for different crops increased. Rice, maize, wheat and barley are the four crops which have shown constant and positive increase in per hectare yield over the time. Per hectare yield of rice was 1009 kilograms in 1960-61 which increased to 3838 kilograms in 2014-15 with an annual growth rate of 2.505 (Table 8 ). Wheat has shown the same positive trend as it's per hectare yield increased from 1244 kilograms to 4304 kilograms an annual growth rate of 2.325 in the same period (Table 8). Barley's 
yield per hectare increased from 798 kilograms to 3580 kilograms during 1960-61 to 2014-15.

All given crops has shown positive growth rates in the given period of 1960-61 to 2014-15. Per hectare yield of barley increased at 2.819 per cent which is highest in all given crops. Annual compound growth rate of yield per hectare of rice was highest in the decade of 1960-61 to 1970-71 at 5.751 after that growth rate in the latter decades decreased for rice. In decade of 2000-01 to 2010-11 annual compound growth rate of yield per hectare of rice increased slightly to 0.883 from 0.826 of previous decade. Growth rate of wheat too decreased over the time from 6.048 to -2.140 per cent (Table 9).

Uses of chemical fertilizers whether it is nitrogenous, phosphatic or potassic was in total 5 thousand nutrients tons in 1960-61. It increased in very high rate. In 1970-71 total use of chemical fertilizers increased to 213 nutrients tons. In 1990-91 crossed one thousand mark and was 1220 nutrients tons. Use of chemical fertilizers has increased extensively over the period of time.

In 2010-11 it almost touched the two thousand mark. But in 2014-15 use of fertilizers decreased from 1911 nutrients tons to 1677 nutrients tons. But it is clear that farmers are using way much chemical fertilizers to get a high yield from their fields and their input expenditure is growing year by year.

Number of tractors used for agricultural purpose has been increasing every year. In 1996-97 total numbers of tractors were 494689 which increased to 768363 in year 2011-12 with an annual growth rate of 2.98 (Table 10). Highest number of tractors has been owned by medium sized farmers in the given period, small sized farmer are at second number in case of owning tractors.

There were only 1016 combine harvesters (tractor powered) in Punjab in 1996-97 and number of combine harvesters increased to 47811 in next five years (Table 11). This shows a huge investment by farmers in agricultural machinery. As in case of tractors highest combine harvesters are also owned by marginal farmers. It can be seen as an investment from which they can earn income by lending these combine harvesters to other farmers for money, but these type of machinery is quite expensive and farmers are spending money on machinery by taking loans from non-institutional agencies mostly (Table 12). This kind of behavior finally drags

Table 6: Production of different crops (thousand metric tons)

\begin{tabular}{ccccccccccc}
\hline Year/ Crops & Rice & Jowar & Bajra & Maize & Wheat & Barley & Total Pulses & Total Oil Seeds & Cotton & Sugarcane \\
$1960-61$ & 229 & 0 & 58 & 371 & 1742 & 52 & 709 & 121 & 709 & 486 \\
$1970-71$ & 688 & 2.8 & 243 & 861 & 5145 & 57 & 308 & 233 & 818 & 527 \\
$1980-81$ & 3233 & 0.8 & 86 & 612 & 7677 & 108 & 204 & 187 & 1178 & 392 \\
$1990-90$ & 6506 & 0.5 & 13 & 333 & 12159 & 101 & 105 & 93 & 1909 & 601 \\
$2000-01$ & 9157 & - & 5 & 461 & 15551 & 109 & 39 & 88 & 1199 & 777 \\
$2010-11$ & 10819 & - & 3 & 491 & 16472 & 44 & 17 & 73 & 1822 & 417 \\
$2014-15(E)$ & 11107 & - & - & 460 & 15088 & 39 & 9 & 58 & 1342 & 581 \\
\hline
\end{tabular}

Source: Statistical abstract of Punjab 2015.

Table 7: Annual compound growth rate of production of different crops

\begin{tabular}{cccccccccc}
\hline Year/ Crops & Rice & Bajra & Maize & Wheat & Barley & Total Pulses & Total Oil Seeds & Cotton & Sugarcane \\
\hline 1960-61 to $1970-71$ & 11.629 & 15.403 & 8.783 & 11.438 & 0.922 & -7.999 & 6.772 & 1.440 & 0.813 \\
1970-71 to $1980-81$ & 16.735 & -9.866 & -3.356 & 4.083 & 6.599 & -4.036 & -2.175 & 3.714 \\
1980-81 to 1990-91 & 7.243 & -17.216 & -5.904 & 4.706 & -0.668 & -6.426 & -6.747 & 4.946 & 4.366 \\
1990-91 to 2000-01 & 3.477 & -9.113 & 3.306 & 2.491 & 0.765 & -9.429 & -0.551 & -4.544 & 2.602 \\
2000-01 to 2010-11 & 1.682 & -4.980 & 0.632 & 0.577 & -8.672 & -7.968 & -1.851 & 4.273 \\
2010-11 to 2014-15 & 0.659 & -100.00 & -1.617 & -2.170 & -2.971 & -14.700 & -5.588 & -7.359 & 8.645 \\
1960-61 to 2014-15 & 7.453 & -100.00 & 0.399 & 4.079 & -0.531 & -7.768 & -1.353 & 1.189 & 0.331 \\
\hline
\end{tabular}

Statistical abstract of Punjab 2015. 
Table 8: Yield per hectare (in kilograms)

\begin{tabular}{|c|c|c|c|c|c|c|c|c|c|c|}
\hline Year/ Crops & Rice & Jowar & Bajra & Maize & Wheat & Barley & Gram & Cotton American & Cotton Desi & Sugarcane \\
\hline $1960-61$ & 1009 & 0 & 472 & 1135 & 1244 & 798 & 813 & 269 & 270 & 3654 \\
\hline 1970-71 & 1765 & 550 & 1176 & 1555 & 2238 & 1022 & 797 & 399 & 338 & 4117 \\
\hline $1980-81$ & 2733 & 739 & 1244 & 1602 & 2730 & 1640 & 582 & 329 & 241 & 5526 \\
\hline 1990-90 & 3229 & 1500 & 1107 & 1786 & 3715 & 2754 & 744 & 481 & 285 & 5941 \\
\hline 2000-01 & 3506 & - & 893 & 2793 & 4565 & 3393 & 953 & 437 & 408 & 6425 \\
\hline 2010-11 & 3828 & - & 1495 & 3415 & 4693 & 3652 & 1300 & 646 & 472 & 5952 \\
\hline 2014-15(E) & 3838 & - & - & 3652 & 4304 & 3580 & 1085 & 546 & 397 & 6186 \\
\hline
\end{tabular}

Source: Statistical abstract of Punjab 2015.

Table 9: Annual compound growth rate of yield per hectare

\begin{tabular}{cccccccccc}
\hline Year/ Crops & Rice & Bajra & Maize & Wheat & Barley & Gram & Cotton American & Cotton Desi & Sugarcane \\
\hline 1960-61 to 1970-71 & 5.751 & 9.559 & 3.199 & 6.048 & 2.505 & -0.199 & 4.021 & 2.272 & 1.200 \\
1970-71 to 1980-81 & 4.469 & 0.564 & 0.298 & 2.007 & 4.843 & -3.095 & -1.911 & -3.326 & 2.987 \\
1980-81 to 1990-91 & 1.682 & -1.160 & 1.093 & 3.129 & 5.320 & 2.486 & 3.871 & 1.691 & 0.727 \\
1990-91 to 2000-01 & 0.826 & -2.125 & 4.573 & 2.082 & 2.109 & 2.507 & -0.955 & 3.653 & 0.786 \\
2000-01 to 2010-11 & 0.883 & 5.288 & 2.031 & 0.277 & 0.738 & 3.154 & 3.986 & 1.468 & -0.762 \\
2010-11 to 2014-15 & 0.065 & -100.00 & 1.692 & -2.140 & -0.497 & -4.419 & -4.117 & -4.234 & 0.969 \\
$1960-61$ to 2014-15 & 2.505 & -100.00 & 2.188 & 2.325 & 2.819 & 0.536 & 1.320 & 0.716 & 0.980 \\
\hline
\end{tabular}

Source: Statistical abstract of Punjab 2015.

Table 10: Use of chemical fertilizers 000 nutrients tons

\begin{tabular}{ccccc}
\hline Year/ fertilizer & Nitrogenous & Phosphatic & Potassic & Total NPK \\
\hline $1960-61$ & 5 & - & - & 5 \\
$1970-71$ & 175 & 31 & 7 & 213 \\
$1980-81$ & 526 & 207 & 29 & 762 \\
$1990-90$ & 877 & 328 & 15 & 1220 \\
$2000-01$ & 1008 & 282 & 23 & 1313 \\
$2010-11$ & 1403 & 435 & 73 & 1911 \\
$2014-15$ (E) & 1321 & 326 & 30 & 1677 \\
\hline
\end{tabular}

Source: Statistical abstract of Punjab 2015.

farmers into debt trap. In 2011-12 total number of combine harvesters increased to 84372 from 75712 during year 2006-07.

Institutional credit of marginal farmers increased from 13.11 crore to 1522.94 crore with an annual growth rate of 34.607 during 1996-97 to 201112 , which is highest among all the farm sizes. Institutional credit of small farmers increased from 39.73 crore to 2064.86 crore with an annual growth rate of 28.008 during the same period. Medium size class has highest institutional credit among all classes. In year 1996-97 its credit was 531.56 crore which increased to 10218.02 in the year 2011-12 with an annual growth rate of 20.292. Total institutional credit of all classes increased from 754.18 crore to 15587.81 crore with a growth rate of 20.839 during 1996-97 to 2011-12 (Table 13). 
Agriculture Situation in Punjab: An Analysis of Transformations from Labour Intensive... $\mathcal{C}$

Table 11: Agricultural tractors

\begin{tabular}{ccccc}
\hline Size class/year & $\mathbf{1 9 9 6 - 9 7}$ & $\mathbf{2 0 0 1 - 0 2}$ & $\mathbf{2 0 0 6 - 0 7}$ & $\mathbf{2 0 1 1 - 1 2}$ \\
\hline Marginal (below 1.0) & 29678 & 43393 & 57080 & 69137 \\
Small (1.0 - 1.99) & 27149 & 82388 & 97139 & 105517 \\
Medium (2.0 - 9.99) & 380506 & 497173 & 495314 & 529211 \\
Large (10 and above) & 57356 & 76990 & 61634 & 64498 \\
All groups & 494689 & 699944 & 711167 & 768363 \\
\hline
\end{tabular}

Source: agriculture census 1996-97, 2001-02, 2006-07, 2011-12.

Table 12: Annual compound growth rate of agricultural tractors

\begin{tabular}{ccccc}
\hline Size class/year & 1996-97 to 2001-02 & 2001-02 to 2006-07 & 2006-07 to 2011-12 & 1996-97 to 2011-12 \\
\hline Marginal (below 1.0 hect.) & 7.89 & 5.64 & 3.91 & 5.80 \\
Small (1.0-1.99 hect.) & 24.86 & 3.35 & 1.67 & 9.47 \\
Medium ( 2.0-9.99 hect.) & 5.49 & -0.07 & 1.33 & 2.22 \\
Large (10 hect. \& above) & 6.06 & -4.35 & 0.91 & 0.79 \\
All groups & 7.19 & 0.32 & 1.56 & 2.98 \\
\hline
\end{tabular}

Source: agriculture census 1996-97, 2001-02, 2006-07, 2011-12.

Table 13: Combine harvester (tractor powered)

\begin{tabular}{ccccc}
\hline Size class/year & $\mathbf{1 9 9 6 - 9 7}$ & $\mathbf{2 0 0 1 - 0 2}$ & $\mathbf{2 0 0 6 - 0 7}$ & $\mathbf{2 0 1 1 - 1 2}$ \\
\hline Marginal (below 1.0 hect.) & 92 & 1421 & 4274 & 7081 \\
Small (1.0 - 1.99 hect.) & 436 & 6635 & 10526 & 12240 \\
Medium (2.0 - 9.99 hect.) & 318 & 31434 & 51752 & 54616 \\
Large (10 hect. \& above) & 170 & 8321 & 9160 & 10435 \\
All groups & 1016 & 47811 & 75712 & 84372 \\
\hline
\end{tabular}

Source: agriculture census 1996-97, 2001-02, 2006-07, 2011-12.

Table 14: Estimated institutional credit taken for agricultural purposes by different size groups (in crore)

\begin{tabular}{ccccc}
\hline Size/year & $\mathbf{1 9 9 6 - 9 7}$ & $\mathbf{2 0 0 1 - 0 2}$ & $\mathbf{2 0 0 6 - 0 7}$ & $\mathbf{2 0 1 1 - 1 2}$ \\
\hline Marginal (below 1.0 hect.) & 13.11 & 80.99 & 250.63 & 1522.94 \\
Small (1.0 - 1.99 hect.) & 39.73 & 218.43 & 560.05 & 2064.86 \\
Medium (2.0 - 9.99 hect.) & 531.56 & 2231.29 & 4807.69 & 10218.02 \\
Large (10 hect. \& above) & 169.77 & 551.98 & 1174.24 & 1781.99 \\
All groups & 754.18 & 3082.72 & 6792.62 & 15587.81 \\
\hline
\end{tabular}

Source: agriculture census 1996-97, 2001-02, 2006-07, 2011-12.

Table 15: Annual compound growth rate of institutional credit

\begin{tabular}{ccccc}
\hline Size class/year & 1996-97 to 2001-02 & 2001-02 to 2006-07 & 2006-07 to 2011-12 & 1996-97 to 2011-12 \\
\hline Marginal (below 1.0 hect.) & 43.935 & 25.349 & 43.460 & 34.607 \\
Small ( 1.0-1.99 hect.) & 40.617 & 20.721 & 29.817 & 28.008 \\
Medium ( 2.0-9.99 hect.) & 33.230 & 16.594 & 16.275 & 20.292 \\
Large (10 hect. \& above & 26.594 & 16.297 & 8.700 & 15.828 \\
All groups & 32.523 & 17.117 & 18.073 & 20.839 \\
\hline
\end{tabular}

Source: agriculture census 1996-97, 2001-02, 2006-07, 2011-12. 


\section{Sum Up and suggestions}

The present paper based on secondary data tried to show the situation of Punjab's agriculture. Number of total operational holdings has declined during 1970-71 to 2010-11 with some ups and downs in between. Share of different size groups has also changed during the same period. Share of small sized farmers remained almost same with some variations during 1970-71 to 2010-11 but there actual number decreased from 260083 to 195439 in the same period. Number of medium sized operational holdings was 528858 in 1970-71 which was 38.45 per cent of total operational holdings. In 2010-11 share of medium sized holdings was 59.19 per cent of total operational holdings and actual number was 622966 with a slight negative change from previous given year 2000-01.

In 1990-91, net area sown was 4218 thousand hectares which increased to 4250 hectares in 2000101. But after that there is a decreasing trend in net area sown, in 2010-11 net area sown decreased to 4158 thousand hectares and farther to 4145 thousand in 2013-14.

In 1970-71, area under rice, bajra, maize, wheat, oil seeds increased from previous decade. But after that decade area under all other crops tend to fall over the time other than the wheat and rice. Area under these two major crops increased during 1960-61 to 2014-15. This shows that crop diversification of agriculture is vanishing and agriculture has entered in mono-crop system.

As the area under rice increases, this is major water consuming crop. Area under rice increased from 227 thousand hectares to 2894 with an annual increase of 4.827 per cent during 1960-61 to 2014-15. More and more water has been used by farmer with less re-chargeability of water level. Water level which was at 6.827 meter in June 1973 decreased to 11.552 meter in 2005. Water level decreased in post monsoon period too. Water level was at 5.9 meter in 1973, it decreased to 10.964 meter in 2005.

Basically Punjab's agriculture is in stagnate stage where increase in production or yield is not as per the expectations of the farmers. After 1970-71 this increase in total production visible only in two crops rice and wheat. All other crops showed fluctuations in production. Production of jowar is zero and production of bajra is only 1 thousand.
Production of pulses has shown a decreasing trend after 1970-71, same can be said for the oil seeds. Total production of cotton, which is a major crop of Malwa region, increased till 1990-91 but after that it is showing fluctuations in its production figures. Rice, maize, wheat and barley are the only four crops which have shown constant and positive increase in per hectare yield over the time.

Uses of chemical fertilizers whether it is nitrogenous, phosphatic or potassic was in total 5 thousand nutrients tons in 1960-61. It increased in very high rate. In 2010-11, it almost touched the two thousand mark. But in 2014-15 use of fertilizers decreased from 1911 nutrients tons to 1677 nutrients tons. But it is clear that farmers are using way much chemical fertilizers to get a high yield from their fields and their input expenditure is growing year by year.

Number of tractors used for agricultural purpose and combine harvesters (tractor powered) has been increasing every year. In 1996-97, total number of tractors were 494689 which increased to 768363 in year 2011-12. There were only 1016 combine harvesters (tractor powered) in Punjab in 1996-97 and number of combine harvesters increased to 47811 in next five years. In 2011-12, total number of combine harvesters increased to 84372 from 75712 during year 2006-07.

Institutional credit of marginal farmers increased from 13.11 crore to 1522.94 crore with an annual growth rate of 34.607 during 1996-97 to 2011-12, which is highest among all the farm sizes. Total institutional credit of all classes increased from 754.18 crore to 15587.81 crore with a growth rate of 20.839 during 1996-97 to 2011-12.

This shows a huge investment by farmers in agricultural machinery. As in case of tractors highest combine harvesters are also owned by marginal farmers. It can be seen as an investment from which they can earn income by lending these combine harvesters to other farmers for money, but these type of machinery is quite expensive and farmers are spending money on machinery by taking loans from institutional and non-institutional agencies mostly. This kind of behavior finally drags famers into debt trap.

From above results we can say that Punjab farmers are suffering from stagnated agricultural production and their expenditure on agricultural inputs are increasing over the time. This situation creates 
financial problems for the farming class. To overcome the losses and meet the expenditure needs farmers take loans. To return the loans many times farmers sell their land and moving outside the agriculture to support their livelihood.

To overcome this situation much needed to be done. Based on review of literature and this paper below are given some suggestions that can help tackling the discussed problem.

1. Institutional credit system must be improved, especially the co-operatives.

2. There is need to change the output pricing policy and input pricing.

3. Facilities provided in rural areas also be improved as compared to the urban area. These facilities increase inequality in rural and urban areas.

4. Government led investment should be increased to agriculture related programs.

\section{REFERENCES}

Chand, R., Lakshmi, P.A. and Singh, A. 2011. Farm size and productivity: Understanding the strengths of smallholders and improving their livelihoods. Economic and Political Weekly, 46)26-27), 5-11.

Junankar, P.N. 1975. Green revolution and inequality. Economic and Political Weekly, 10(13): A15-A18.
Khusro, A.M. 1964. Returns to scale in Indian agriculture. Indian Journal of Agricultural Economics, 19: 51-80.

Sanyal, S.K. 1969. Size of holding and some factors related to production. Economic and Political Weekly, 4(33): 1345-1347.

Shah, A.C. 1961. Credit for small farmers. Indian Journal of Agricultural Economics, 16(3): 56-59.

Sharma, V.K.,Vashishtha S.V. and Singh, D. 2006. Causes of indebtedness among the farmers. Indian Research Journal of Extension Education, 6(3): 1-3.

Sidhu, H.S. 2002. Crisis in agrarian economy in Punjab: Some urgent steps, Economic and Political Weekly, 37(300, 3132-3138.

Singh, K. 2011. Ground depletion in Punjab: Measurement and countering strategies. Indian Journal of Agricultural Economics, 66(4): 573-589.

Singh, R.D. and Mehrotra, M.K. 1973. Problem of credit and indebtedness with the small and marginal farmers and agricultural labourers. Indian Co-operative Review, 10(2): 205-222.

Singh, S., Kaur, M. and Kingra, H.S. 2008. Indebtedness among farmers in Punjab. Economic and Political Weekly, 43(26-27): 130-136.

Sivakumar, S.S. 1978. Aspects of agrarian economy in Tamil Nadu: A study of two villages. Economic and Political Weekly, 13(18): 762-770.

Tewari, S.C. 1969. Agriculture indebtedness in hilly farms of Uttar Pradesh. Indian Journal of Economics, 49(1): 449-452.

Vaidyanathan, A. 2006. Agrarian crisis: nature, causes, and remedies. The Hindu. 
